\title{
PERMANENCE OF WATER EFFECTIVENESS IN THE ROOT ZONE OF THE CAATINGA BIOME ${ }^{1}$
}

\author{
CARLOS ALEXANDRE GOMES COSTA ${ }^{2 *}$, JOSÉ CARLOS DE ARAÚJO ${ }^{2}$, JOSÉ WELLINGTON BATISTA LOPES ${ }^{2}$, \\ EVERTON ALVES RODRIGUES PINHEIRO ${ }^{3}$
}

\begin{abstract}
Soil is an important water compartment into a watershed scale, mainly due to its role in providing water to plants and to the influence of antecedent moisture on the runoff initiation. The aim of this research is to assess the permanence of water effectiveness in the soil under preserved-vegetation constraints in the Caatinga biome, in the semiarid northeastern Brazil. For this purpose, hourly soil moisture measurements were collected with TDR and analyzed between 2003 and 2010 for three soil-vegetation associations in the Aiuaba Experimental Basin. The results showed that in nine months per year soil moisture was below wilting point for two associations, whose soils are Chromic Luvisol and Haplic Lixisol (Abruptic). In the third association, where the shallow soil Lithic Leptosol prevails, water was found non-effective four months per year. A possible reason for the high water permanence in the shallowest soil is the percolation process, generating sub-surface flow, which barely occurs in the deeper soils. In situ observations indicates that the long period of soil moisture below the wilting point was not enough to avoid the blooming season of the Caatinga vegetation during the rainy periods. Indeed, after the beginning of each rainy season, there is a growth of dense green vegetation, regardless of the long period under water shortage.
\end{abstract}

Keywords: Wilting point. Soil. Semiarid environment.

\section{PERMANÊNCIA DA EFETIVIDADE DA ÁGUA NA ZONA DE RAÍZES NO BIOMA CAATINGA}

RESUMO - O solo é um dos compartimentos de água de maior importância em uma bacia hidrográfica. A vegetação depende majoritariamente da água retida pelo solo para atender às suas demandas; e o início do escoamento superficial depende fortemente da umidade inicial do solo. Este estudo teve como objetivo avaliar a permanência da efetividade da água no solo sob condições de vegetação preservada no bioma Caatinga, Semiárido do Nordeste brasileiro. Para isso, foram analisados dados horários de umidade do solo através de sensores TDR obtidos entre os anos de 2003 e 2010 para três associações solo-vegetação presentes na Bacia Experimental de Aiuaba. Os resultados indicam que, durante nove meses ao ano, a água no solo encontra-se abaixo do ponto de murcha permanente para duas associações, cujos solos são Argissolo Vermelho-Amarelo e Luvissolo Hipocrômico. Na terceira associação, cujo solo é raso (Neossolo litólico), a água encontra-se não efetiva durante quatro meses ao ano. Avalia-se que a maior permanência de água neste solo dê-se pela limitação de percolação profunda, induzindo o escoamento sub-superficial; o que não se verifica nos solos mais profundos. Verificou-se in situ que o longo período de umidade abaixo do ponto de murcha permanente não comprometeu a vida das espécies da Caatinga. Após o início de cada período chuvoso, observa-se o crescimento de uma densa massa de vegetação, apesar do longo período sob estresse hídrico.

Palavras-chave: Ponto de murcha permanente. Solo. Semiárido.

\footnotetext{
${ }^{*}$ Corresponding author

${ }^{1}$ Received for publication in $05 / 06 / 2015$; accepted in $02 / 18 / 2016$.

Paper extracted from the doctoral thesis of the first author.

${ }^{2}$ Department of Agricultural Engineering, Universidade Federal do Ceará, Fortaleza, CE, Brazil; costacag@gmail.com, jcaraujo@ufc.br, wellingtonjwl@gmail.com.

${ }^{3}$ Doctorate student, Escola Superior de Agronomia Luiz de Queiroz, Universidade de São Paulo, Piracicaba, SP, Brazil, evertonvest@yahoo.com.br.
} 


\section{INTRODUCTION}

The coexistence of society with the semiarid necessarily requires greater knowledge of its processes and its potential. Recent research carried out in the Brazilian semi-arid region demonstrated the importance of the soil both in the surface flow initiation and as a water reservoir for vegetation (FIGUEIREDO et al. 2016; PINHEIRO et al. 2016). Most studies indicate the surface reservoirs as the main water container within a watershed (DE ARAUJO et al., 2004; MALVEIRA et al, 2012). However, the soil plays an important role in the storage of water. As regards arid and semi-arid ecosystems, soil water is of utmost importance to biogeochemical cycles and recycling nutrients (WANG 2012). In addition, it must be considered that the water strongly interacts with atmospheric processes, e.g., evapotranspiration, air temperature and rainfall (SENEVIRATNE et al. 2010; PINHEIRO et al. 2016).

The analysis of the association between soil and vegetation allows better management and use of natural resources (AULER et al. 2014), which is important for the understanding of the hydrological links between soil and vegetation, mainly for waterscarce regions. The scarcity of data and high spatial variability of such regions (COSTA et al. 2012, 2013) contribute to the poor understanding of such relationships. The main link of the soil-vegetation system is the root zone. Therefore, to move forward on the knowledge of this subject, it is necessary to understand the interactions between soil and roots.

The dynamics of the water in the soil in the root zone is mainly characterized by the processes of infiltration, deep percolation, underground flow, retention and root water uptake (DE JONG VAN LIER et al., 2008; DE JONG VAN LIER; VAN DAM; METSELAAR, 2009). These processes are strongly influenced by soil hydraulic properties in all its complexity and heterogeneity, which hinders their understanding. Thereby, the investigation of the temporal distribution of soil-water effectiveness in a preserved area, based on measured soil water content, can contribute to the understanding of these processes. In the Caatinga, investigation of this subject is still rare. On the scale of watersheds in the semiarid region of Brazil, relevant research can be cited, however, with greater focus on sedimentological processes, such as Antonino et al. (2004); Figueiredo et al. (2016); Rodrigues et al. (2009);Montenegro and Ragab (2010; 2012); Neves et al. (2010); Costa et al. (2013);Silva, Montenegro and Santos (2012); Souza et al. (2011).

The method of permanence curves (describe the probabilistic distribution of an event to happen or be overcome) has been often used to explain the temporal dynamics of water availability (PINHEIRO and NAGHETTINI 2010; NOVAES et al. 2009; SILANS; ALMEIDA; PORTO 2009; CRUZ and TUCCI 2008; BLANCO; SECRETAN; FAVRE 2007; DE ARAÚJO, GÜNTNER and BRONSTERT 2006; DE ARAÚJO and PIEDRA 2009; CAMPOS 2010). However, there are few applications of the method in relation to the availability of water in the soil. Therefore, it is the objective of this study to evaluate the interaction between the soil water content and the Caatinga vegetation in terms of water availability, using water effectiveness of permanence curves in the root zone.

\section{MATERIAL AND METHODS}

\section{Study Area}

The study was conducted in the Aiuaba Experimental Basin (AEB) (Figure 1), with total area of $12 \mathrm{~km}^{2}$, located in the municipality of Aiuaba, State of Ceará, Brazil, coordinates $6^{\circ} 42^{\prime} \mathrm{S}$ and $40^{\circ}$ $17^{\prime} \mathrm{W}$.

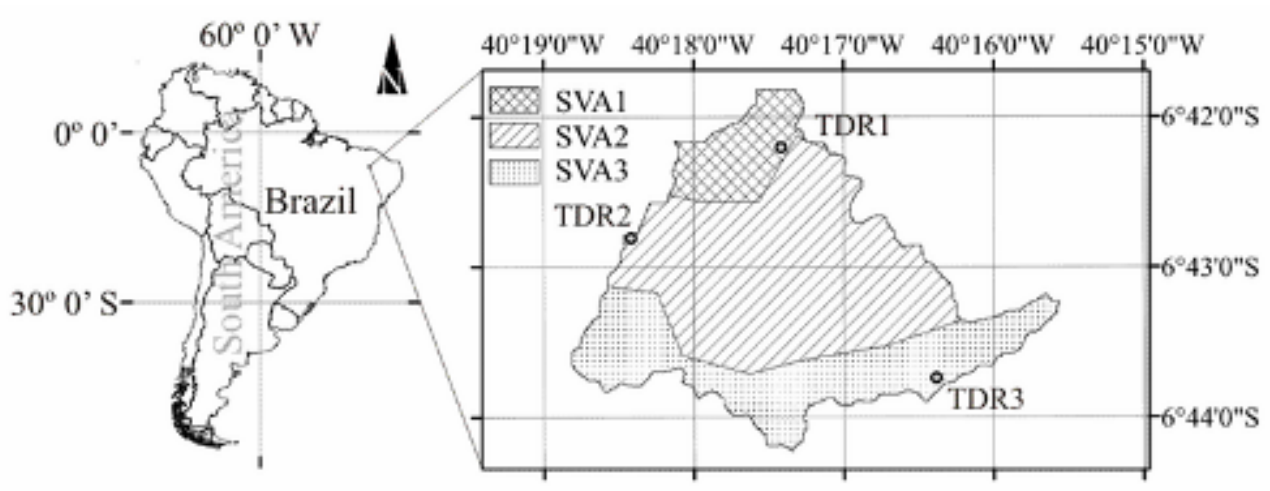

Figure 1. Geographical location of the study area and instrumentation of the Aiuaba Experimental Basin (AEB). The SVA and TDR acronyms mean soil-vegetation association and time domain reflectometry, respectively.

The AEB, the largest federal conservation unit of the Caatinga biome, is fully preserved, located wholly within the Ecological Station of Aiuaba, and ruled by the Brazilian Federal 
Environmental Institute(DE ARAUJO; PIEDRA, 2009). The climate is Bsh, according to Köppen classification, with average rainfall of $560 \mathrm{~mm} \mathrm{yr}^{-1}$; evaporation of class A pan of $2500 \mathrm{~mm} \cdot \mathrm{yr}^{-1}$; and average runoff coefficient below $1 \%$ (FIGUEIREDO et al. 2016).

With regard to the hydrologic variables, the basin has been continuously monitored by the Hydro -sediment logical Research Group of Semi-Arid (www.hidrosed.ufc.br) since January 2003. Among the main instruments installed in the basin, there are one climatological station, a water-level meter in a lake, three river-flow gauge stations, three rain gauge stations, three soil moisture sensors, one class Apan, a $100-\mathrm{m}^{2}$ interception site, a monitored slope with pins and a sediment sampler. For more information on the Aiuaba Experimental Basin (AEB), refer to Medeiros, de Araújo and Andrello (2014); Medeiros and de Araujo (2014); Costa et al. (2013); Pinheiro, Costa and de Araújo (2013).

The study area is divided into three main soilvegetation associations (SVA, see GÜNTNER; BRONSTERT 2004; PINHEIRO, COSTA; DE ARÁUJO 2013). The first association (SVA1), whose land designation is Haplic Lixisol (Abruptic), occupies $20 \%$ of the basin area and has the Caesalpinia pyramidalis Tul. (popular name: Catingueira) as representative tree species. The second association (SVA2) has aChromic Luvisolwith the prevailing tree Piptadenia obliqua (popular name: Angelim), which occupies 34\% of the basin area.The third association (SVA3), which occupies $46 \%$ of the area of the AEB, has Lithic Leptosoland is represented by the Mimosa tenuiflora (Willd) Poir (popular name Jurema Preta). The choice of representative trees was based on the size and frequency in each SVA as presented by Pinheiro, Costa and Araújo (2013).

\section{Soil moisture monitoring}

The evaluation of the soil water content is obtained based on the dielectric constant using the time domain reflectometry. The direct measurement is the time of transmission/reflection of an electromagnetic pulse issued by a pulse generator in parallel metal rods that serve as waveguides. The estimated dielectric constant is from the material between the metallic rods, in this case, the soil-water system.

The equipment used in this monitoring are three TDR type sensors spatially distributed in each SVA (Figure 1). Each set consists of a probe with two stainless steel rods with $0.30 \mathrm{~m}$ length each interconnected via a cable, to a memory device (data logger), where data are stored in the range of microseconds (ms), corresponding to the pulse response time between the steel rods. The storage capacity of these devices allows the accumulation of data for approximately four consecutive months. Bimonthly campaigns were carried out to transfer this information to the database. As previously mentioned, the monitoring program started in January 2003.Costa et al.(2013) performed the sensors in situ calibration for improved data reliability.

\section{Permanence of water effectiveness in the soil}

An important parameter in the assessment of water availability and actual evapotranspiration estimated is the soil water effectiveness (SWE). Chen et al. (2007) assume that the effectiveness of water in the soil for the plants is higher at field capacity, and decreases with decreasing soil moisture. At the permanent wilting point, soil water is not anymore in principle - available to plants, i.e., the effectiveness of soil moisture is at its lowest limit. Application of this method was reported by Downer and Ogden (2004) in modeling the actual evapotranspiration. The soil water effectiveness at the root zone (SWErz) was calculated from the Equation 1 (PORPORATTO et al. 2002), and can be classified into five groups (Table 1). Table 2 presents the hydro-physical parameters of the soils of the three soil-vegetation associations.

$$
\begin{aligned}
& S W E_{r z}=\frac{A W_{r z}}{A W C_{r z}} \\
& A W_{r z}=\left(\theta_{i}-\theta_{W P}\right) x R_{e f} \\
& A W C_{r z}=\left(\theta_{F C}-\theta_{W P}\right) x R_{e f}
\end{aligned}
$$

In Equations $1-3, \theta_{\mathrm{FC}}$ is the field capacity $\left(\mathrm{m}^{3} \mathrm{~m}^{-3}\right)$; $\theta_{\mathrm{WP}}$ is the permanent wilting point $\left(\mathrm{m}^{3} \mathrm{~m}^{-3}\right) ; \theta_{i}$ is the soil water content at time $i\left(\mathrm{~m}^{3} \mathrm{~m}^{-3}\right)$; and $R_{e f}$ is the effective root depth $(\mathrm{mm})$. For further information about the effective root depth in the Caatinga, refer to Pinheiro, Costa and de Araújo, (2013).

Table 1. Effectiveness criteria of the soil water according to Chen et al. (2007).

\begin{tabular}{clcl}
\hline SWE & Effectiveness & SWE & Effectiveness \\
\hline$>1.00$ & Extremely effective & $0.25-0.50$ & Low effectiveness \\
$0.75-1.00$ & Highly effective & $0.00-0.25$ & Marginally effective \\
$0.50-0.75$ & Moderately-highly effective & $<0.00$ & Not effective \\
\hline
\end{tabular}


Table 2. Hydro-physical parameters of the soils: texture, soil bulk density $\left(\rho_{\text {soil }}\right)$, soil moisture at the point of saturation $\left(\theta_{\mathrm{SAT}}\right)$, soil moisture at field capacity $\left(\theta_{\mathrm{FC}}\right)$, soil moisture at wilting point $\left(\theta_{\mathrm{WP}}\right)$, and residual soil moisture $\left(\theta_{\mathrm{RM}}\right)$ of the three soil types at the Aiuaba Experimental Basin (AEB). In the Table, SVA means soil-vegetation association; ALI means Haplic Lixisol (Abruptic); LUV means Chromic Luvisol; and LEP means Lithic Leptsol.

\begin{tabular}{cccccccccc}
\hline SVA & Soil & Sand & $\begin{array}{c}\text { Silt } \\
\text {---------(\%)---------- }\end{array}$ & Clay & $\begin{array}{c}\rho_{\text {soil }} \\
\left(\mathrm{g} \mathrm{cm}^{-3}\right)\end{array}$ & $\theta_{\text {SAT }}$ & $\theta_{\text {FC }}$ & $\begin{array}{c}\theta_{\text {WP }} \\
----------\left(\mathrm{m}^{3} \cdot \mathrm{m}^{-3}\right)----------\end{array}$ & $\theta_{\text {RM }}$ \\
\hline 1 & LIX & 35 & 54 & 11 & 1.44 & 0.437 & 0.276 & 0.110 & 0.020 \\
2 & LUV & 31 & 48 & 21 & 1.21 & 0.529 & 0.220 & 0.120 & 0.016 \\
3 & LEP & 61 & 35 & 4 & 1.47 & 0.414 & 0.117 & 0.050 & 0.009 \\
\hline
\end{tabular}

To obtain a long-term curve, the probability $(\mathrm{P})$ of the moisture measurement to be overcome over time was analyzed (Equation 4).

$$
P\left(\theta \geq \theta_{m}\right)=\frac{m-b}{n+1-2 b}
$$

In which: $\mathrm{m}=$ denotes the decreasing rank order of each soil-moisture measurement; $n=$ total number of observed soil moisture values; $\mathrm{b}=$ parameter of Chegodayev's formula $(\mathrm{b}=0.3)$ (CHOW, MAIDMENT, MAYS 1988).

The results obtained in the analysis of the spatial-temporal distribution of soil moisture (January 2003 to December 2010) allowed the construction of the permanence curves, in a similar manner to that used for surface reservoirs (CAMPOS 2010; de ARAÚJO, PIEDRA 2009). The permanence was associated with categories of effectiveness of water in the soil (Table 1) and physical-hydric soil parameters obtained in the field (Table 2). The field capacity and the wilting point were assessed in the laboratory as a recommendation of EMBRAPA (1997), who consider the soil moistures referring to tensions of $0.033 \mathrm{MPa}$ and 15 $\mathrm{MPa}$, respectively.

\section{RESULTS AND DISCUSSIONS}

In Figure 2, there are two types of permanence curves, with different behavior. The curves of SVA1 and SVA2 presented similar behavior, while the SVA3 curve presented a different shape, probably due to the shallowness of the Lithic Leptosol. The decay of the curves in SVA1 and SVA2 is smooth, while in SVA3 there are two distinct features: at first, for effectiveness index above zero, the curve presented a steep decay; whereasfor negative effectiveness index, the curve hada smooth decay.Downer and Ogden (2004) assessed real evapotranspiration using the soil water effectiveness index and the potential evapotranspiration. From Figure 3, one can observe that during $72 \%$ of the monitoring period for SVA1 and during $75 \%$ for SVA2, water was not effective in soil. For SVA3, due to the low value of the boundary range of permanent wilting point, during only $25 \%$ of the period, water was found not effective. Besides, during $21 \%$ of the monitoring time, water presented only marginal effectiveness. Accordingly, Santos, Araújo and Albuquerque (2011) estimated that during more than $45 \%$ of the monitoring period, the soil moisture was assessed as ineffective. These authors investigated, in the Brazilian semiarid State of Paraíba, soil moisture conditions under three cover conditions: natural vegetation, palm and bare soil.

During the dry season, it can be observed that the water in the shallow soil remains ineffective during $30 \%$ of the period, whereas in the deeper soils, it corresponded to approximately $50 \%$ of the time. Although small $\left(12 \mathrm{~km}^{2}\right)$, the basin is located exactly on the border between areas of crystalline and sediment bedrock. The SVA3 is located in the upper basin, where the relief is flat to undulating; with very shallow soil over little weathered crystalline substrate. Contrastingly, SVA1 and SVA2 are located on the sedimentary area, with very deep water level and high infiltration capacity (DE FIGUEIREDO et al. 2016). The higher prevalence of effective water at SVA3 is probably due to the limitation of deep percolation, since in this case there is a deterrent layer generated by the crystalline. It is assumed that, in this association, relevant subsurface flow occurs, which is not observed in the deeper soils of SVA1 and SVA2.The occurrence of subsurface flow could be the most plausible explanation for the higher water retention in the shallow soil. 


\section{A. G. COSTA et al.}
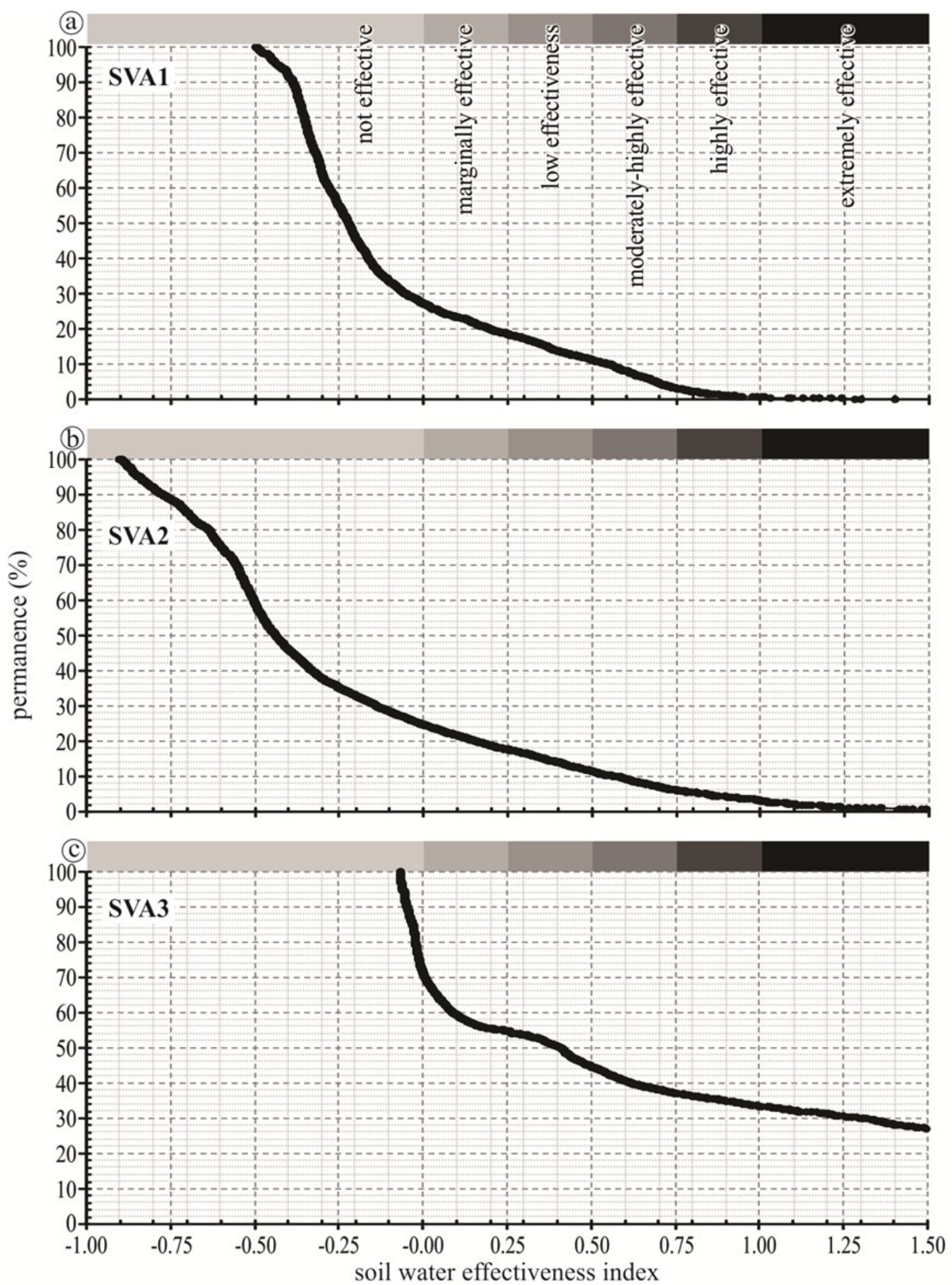

Figure 2. Permanence curvesfor soil moisture and water effectiveness in the AEBsoils for the period 2003-2010: a) soilvegetation association SVA1; b) soil-vegetation association SVA2; c) soil-vegetation association SVA3. 


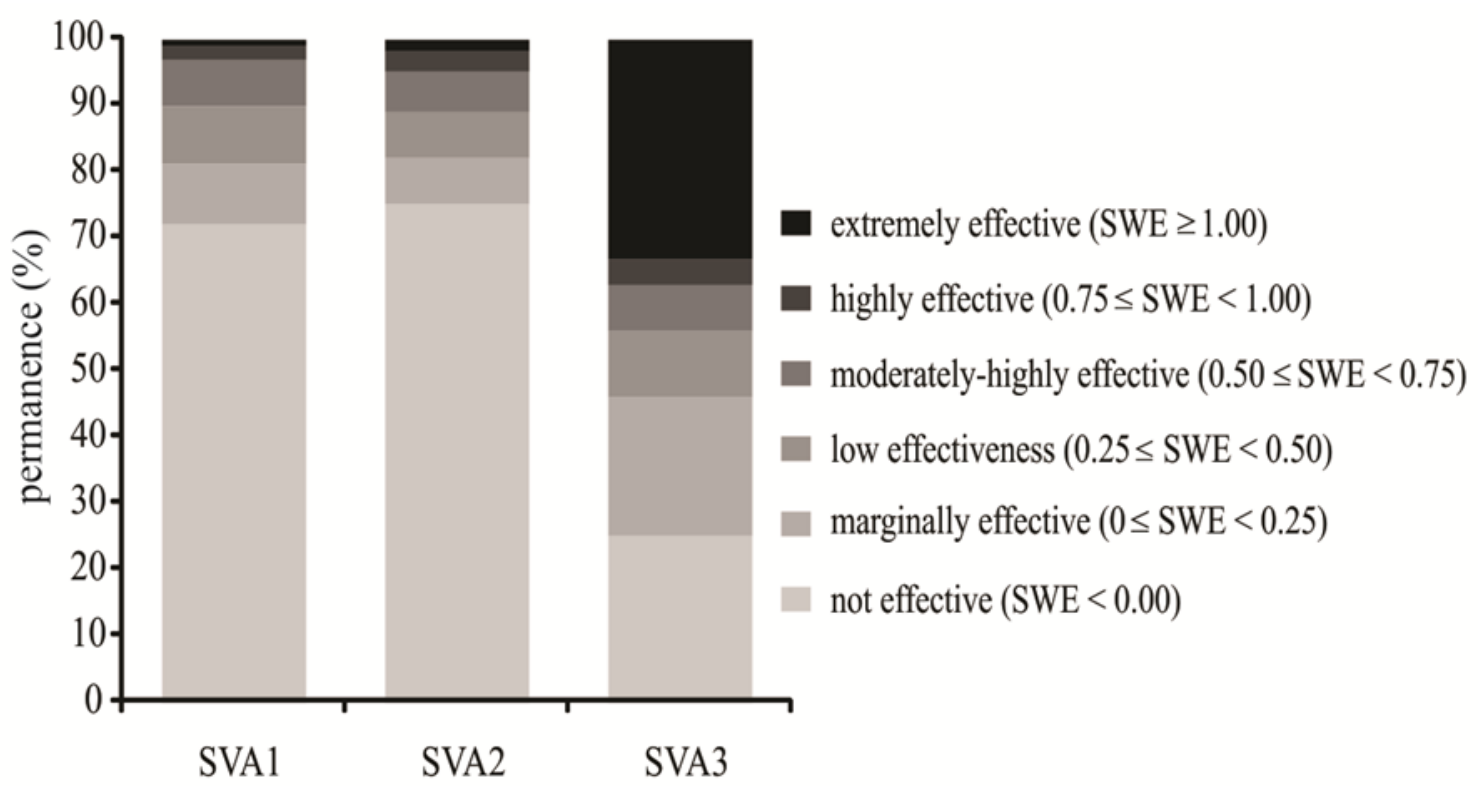

Figure 3. Frequency of the water effectiveness in the root zone of the AEBsoils (2003-2010).

However, in associations whose soils are deeper (SVA1 and SVA2), the soil moisture in the root depth is not effective during over $70 \%$ of the time, which is equivalent to nearly nine months per year below the permanent wilting point. Even under such constraints, the Caatinga vegetation does not dry permanently, recovering from the adverse conditions shortly after the start of the next rainy season. According to in situ observation, the vegetation has larger trees and increased density of plants in SVA1 and SVA2, when compared with SVA3.This different behavior of SVA3 regarding soil water dynamic is due to the presence of a very stony shallow layer $(0.4 \mathrm{~m})$ downwards which causes limited bottom flux, and thus enhancing surface and subsurface runoff. Therefore, plants that compose the SVA3 may have developed specific survival strategies to cope with its restricted soil depth and water dynamics. The effective moisture data available in the experimental basin soils can bring in its wake indications of the type of trees with higher prevalence. In this sense, we recommend that in further research the association between type and depth of soil, available water and prevailing vegetation should be investigated.

\section{CONCLUSIONS}

The results obtained in this study for three soil-vegetation associations (SVA) of the Caatinga biome, using as analytical method the water retention curves in the root zone, allow the following conclusions: (i) the depth of soil associated with the type of bedrock (crystalline or sedimentary) controls the dynamics of water effectiveness in the root zone; (ii) during the rainy season, the shallowest soil presented higher effectiveness than the deeper soils.
It can be inferred that the prevailing surface-runoff process in the shallow soil is through saturation, as opposed to the deeper soils, where the runoff mostly comes from Hortonian processes; (iii) during the dry season, the water in the shallow soil remained during $30 \%$ of the time (about four months per year) no-effective, whereas in the deeper soils, the no-effectiveness took place in more than $70 \%$ of the time (nearly nine months per year); (iv) although the soil moisture in the Caatinga lies below the permanent wilting point for several months, the vegetation recovers quickly after the start of the rainy season, which gives an insight into the significant regeneration capacity of the biome.

\section{REFERENCES}

ANTONINO, A. C. D. et al. A simplified water transfer model of the reservoir- ebb tide system, including preferential flow, in the semi- arid region in Northeastern Brazil. Journal of Hydrology, Amsterdam, v. 287, n. 1-4, p. 147-160, 2004.

AULER, A. C. et al. Soil physico-hydrical properties resulting from the management in Integrated Production Systems. Revista Ciência Agronômica, Fortaleza, v. 45, n. 5, p. 976-989, 2014.

BLANCO, C. J. C.; SECRETAN, Y.; FAVRE, A. Análise, aplicação e transposição de um modelo chuva-vazão para simulação de curvas de permanência de pequenas bacias da Amazônia. Revista Brasileira de Recursos Hídricos, Porto Alegre, v. 12, n. 1, p. 205-216, 2007.

CAMPOS J. N. B. Modeling the Yield-EvaporationSpill in the Reservoir Storage Process: The 
Regulation Triangle Diagram. Water Resources Management, Amsterdam, v. 24, n. 13, p. $3487-$ 3511, 2010.

CHEN, L. et al. The effect of land cover/ vegetation on soil water dynamic in the hilly area of the loess plateau, China. Catena, Amsterdam, v. 70, n. 2, p. 200-208, 2007.

CHOW, V. T.; MAIDMENT, D.; MAYS, L. W. Applied Hydrology. McGraw Hill, 1988. 572 p.

COSTA, A. C. et al. Analysis of channel transmission losses in a dryland river reach in north-eastern Brazil using streamflow series, groundwater level series and multi-temporal satellite data. Hydrological Processes, New York, v. 27, n. 7, p. 1046-1060, 2013.

COSTA, A. C.; BRONSTERT, A.; DE ARÚJO, J. C. A channel transmission losses model for different dryland rivers. Hydrology and Earth System Sciences, Munique, v. 16, n. 4, p. 11111135, 2012.

COSTA, C.A.G. et al. Spatial behaviour of soil moisture in the root zone of the Caatinga biome. Revista Ciência Agronômica, Fortaleza, v. 44, n. 4, p. 685-694, 2013.

CRUZ, J. C.; TUCCI, C. E. M. Estimativa da disponibilidade hídrica através da curva de permanência. Revista Brasileira de Recursos Hídricos, Porto Alegre, v. 13, n. 1, p. 111-124, 2008.

DE ARAÚJO, J. C.; PIEDRA J. I. G. Comparative hydrology: analysis of a semiarid and a humid tropical watershed. Hydrological Processes, New York, v. 23, n. 8, p. 1169-1178, 2009.

DE ARAÚJO, J. C. et al. Water scarcity under scenarios for global climate change and regional development in semiarid Northeastern Brazil. Water International, Amsterdam, v. 29, n. 2, p. 209-220, 2004.

DE ARAÚJO, J. C.; GÜNTNER, A.; BRONSTERT, A. Loss of reservoir volume by sediment deposition and its impact on water availability in semiarid Brazil. Hydrological Sciences Journal des Sciences Hydrologiques, Wallingford, v. 51, n. 1, p. 157-170, 2006.

DE JONG VAN LIER, Q.; VAN DAM, J. C.; METSELAAR, K. Root Water Extraction under Combined Water and Osmotic Stress. Soil Science Society of America Journal, Madison, v. 73, n. 3, p. 862-875, 2009.
DE JONG VAN LIER, Q. et al. Macroscopic Root Water Uptake Distribution Using a Matric Flux Potential Approach. Vadose Zone Journal, Madison, v. 7, n. 3, p. 1065-1078, 2008.

DOWNER, C. W.; OGDEN, F. L. Appropriate vertical discretization of Richards equation for twodimensional watershed-scale modelling. Hydrological Processes, New York, v. 18, n. 1, p. 1 $-22,2004$

CLAESSEN, M. E. C. et al. Manual de métodos de análise de solo. 2. ed. Rio de Janeiro, RJ: EMBRAPA, 1997. 212 p.

FIGUEIREDO, J. V. et al. Runoff initiation in a preserved semiarid Caatinga small watershed, Northeastern Brazil. Hydrological Processes, New York, 2016. DOI: 10.1002/hyp.10801

GÜNTNER, A.; BRONSTERT, A. Representation of landscape variability and lateral redistribution processes for large-scale hydrological modelling in semi-arid areas. Journal of Hydrology, Amsterdam, v. 297 , n. $1-4$, p. $136-161,2004$

JUHÁSZ, C. E. P. et al. Dinâmica físico-hídrica de uma toposseqüência de solos sob savana florestada (cerradão) em Assis, SP. Revista Brasileira de Ciência do Solo, Viçosa, v. 30, n. 3, p. 401-412, 2006.

LARCHER, W. Ecofisiologia Vegetal. São Carlos, SP: RIMA, 2004. 531 p.

MALVEIRA, V.; de ARAÚJO, J.; GÜNTNER, A. Hydrological Impact of a High-Density Reservoir Network in Semiarid Northeastern Brazil. Journal of Hydrologic Engineering, Reston, v. 17, n. 1, p. 109 $116,2012$.

MEDEIROS, P. H. A. et al. Modelling spatiotemporal patterns of sediment yield and connectivity in a semi-arid catchment with the WASA-SED model. Hydrological Sciences Journal des Sciences Hydrologiques , Wallingford, v. 55, n. 4, p. 636$648,2010$.

MEDEIROS, P. H. A.; DE ARAÚJO, J. C.; ANDRELLO, A. C. Uncertainties of the 137Cs technique for validation of soil redistribution modelling in a semiarid meso-scale watershed. Engenharia Agrícola, Jaboticabal, v. 34, n. 2, p. 222-235, 2014

MEDEIROS, P. H. A.; DE ARAÚJO, J. C. Temporal variability of rainfall in a semiarid environment in Brazil and its effect on sediment transport processes. Journal of Soils and Sediments, Heidelberg, v. 14 n. 7, p. $1216-1223,2014$ 
MONTENEGRO, A. A. A.; RAGAB, R. Hydrological response of a Brazilian semi-arid catchment to different land use and climate change scenarios: a modelling study. Hydrological Processes, New York, v. 24, n. 19, p. 2705-2723, 2010.

MONTENEGRO, S. M. G.; RAGAB, R. Impact of possible climate and land use changes in the semi arid regions: A case study from North Eastern Brazil. Journal of Hydrology, Amsterdam, v. 434-435, n. 1, p. 55-68, 2012.

NEVES, A. L. R. et al. Monitoring soil coverage and yield of cowpea furrow irrigated with saline water at different phenological stages. Revista Ciência Agronômica, Fortaleza, v. 41, n. 1, p. 56 - 59, 2010.

NOVAES, L. F. et al. Modelo para a quantificação da disponibilidade hídrica: Parte 2 - Análise do comportamento do modelo para a estimativa da Q7,10 na Bacia do Paracatu. Revista Brasileira de Recursos Hídricos, Porto Alegre, v. 14, n. 1, p. $27-$ 39, 2009.

PINHEIRO, E. A. R. et al. Importance of soil-water to the Caatinga biome, Brazil. Ecohydrology, Londres, 2016. DOI: 10.1002/eco.1728

PINHEIRO, E. A. R.; COSTA, C. A. G.; DE ARAÚJO, J. C. Effective root depth of the Caatinga biome. Journal of Arid Environments, Amsterdam, v. 89, n. 1, p. 1-4, 2013.

PINHEIRO, V. B.; NAGHETTINI, M. Calibração de um modelo chuva-vazão em bacias sem monitoramento fluviométrico a partir de curvas de permanência sintéticas. Revista Brasileira de Recursos Hídricos, Porto Alegre, v. 15, n. 2, p. 143 $-156,2010$

PORPORATTO, A. et al. Ecohydrology of watercontrolled ecosystems. Advances in Water Resources, Amsterdam, v. 25, n. 8-12, p. 13351348, 2002.

RODRIGUES, J. O. et al. Sazonalidade de variáveis biofísicas em regiões semiáridas pelo emprego do sensoriamento remoto. Engenharia Agrícola, Jaboticabal, v. 29, n. 3, p. 452-465, 2009.

SANTOS, J.; ARAÚJO, E. L. ; ALBUQUERQUE, U. P. Richness and distribution of useful woody plants in the semi-arid region of northeastern Brazil. Journal of Arid Environments, Amsterdam, v. 72, n. 5 , p. $652-663,2008$

SENEVIRATNE, S. L. et al. Investigating soil moisture-climate interactions in a changing climate: A review. Earth-Science Reviews, Amsterdam, v.
99, n. 3-4, p. 125-161, 2010.

SILANS, A. M. B. P. de, ALMEIDA, C. das N.; PORTO, R. de Q. Impacto da incerteza na representatividade da repartição espacial da precipitação sobre os hidrogramas e as curvas de permanência obtidos de um modelo chuva-vazão distribuído. Revista Brasileira de Recursos Hídricos, Porto Alegre, v. 14, n. 2, p. 59-71, 2009.

SILVA, J. R. L. da; MONTENEGRO, A. A. A.; SANTOS, T. E. M. dos. Caracterização física e hidráulica de solos em bacias experimentais do semiárido brasileiro, sob manejo conservacionista. Revista Brasileira de Engenharia Agrícola e Ambiental, Campina Grande, v. 16, n. 1, p. 27-36, 2012.

SOUZA, E. R. et al. Temporal stability of soil moisture in irrigated carrot crops in Northeast Brazil. Agricultural Water Management, Amsterdam, v. 99 , n. 1, p. $26-32,2011$

STREDA, T. et al. Effective use of water by wheat varieties with different root system sizes in rain-fed experiments in Central Europe. Agricultural Water Management, Amsterdam, v. 104, n.1, p. 203-209, 2012.

WANG, L. et al. Dryland ecohydrology and climate change: critical issues and technical advances. Hydrology 